\title{
The Dechlorination Reaction of Food Waste and Growth Changes of Lettuce through the Utilization of Soil Bacteria
}

\author{
Soojung Lee and Seokyoon Chang
}

\begin{abstract}
This research was conducted to transform food waste into 'char', which would lead to improving soil quality, preventing acidification and serving as a habitat for numerous microorganisms. The injection of soil bacteria will reduce damages caused by $\mathrm{NaCl}$ within disposed food waste.

Changes in soil bacteria led by variations in the $\mathrm{NaCl}$ concentration were investigated, and by treating the $\mathrm{NaCl}$ solution on lettuce seeds with different amounts of soil bacteria, changes in the chlorophyll of lettuce were identified. Finally, the effects of producing char with food waste that includes soil bacteria and adding soil bacteria after producing the char were compared. The analysis was done by observing the resulting lettuce growths.

The result demonstrated that some soil bacteria cause dechlorination, and the small amount of decomposed chloride ions facilitate plant growth. The optimal method of utilizing food waste char is to produce it first and add soil bacteria on it afterwards.
\end{abstract}

Index Terms - Char, dechlorination, food waste, soil bacteria.

\section{INTRODUCTION}

Around the world, roughly one third of the food producedapproximately 1.3 billion tons, gets wasted every year [1]. The issue of food waste has disconcerted people all over the world for many years. The negative outcome of disposed food is not only limited to just financial matters, but also leads to an exponential loss of resources as a whole that is critical for humans [1].

Changing food waste into char has been suggested as a solution to reduce the problems of food waste. There are currently few patents related to transforming food waste into char, most of which are related to dehydration of food waste and grinding the outcomes [2]. Although such methods are not widely implemented in our society and regardless of how much food waste char is being produced, food waste char is known to have some key positive influences. One research suggests that it can actually remove heavy metals from the soil- the food waste char that included waste wood effectively eliminated lead, but not zinc and nickel [3].

Soil salinity, one of the issues resulting from disposing food waste into the soil is one of the major drawbacks for agriculture in many regions of the world, because salinity decreases the rate of photosynthesis and plant growth. Ref. [4] High sodium contents result in destruction of the soil structure

Manuscript received April 24, 2015; revised June 24, 2015. This work was supported in part by Nature Science Institute.

Soojung Lee and Seokyoon Chang are with Hankuk Academy of Foreign Studies, Wangsan-Ri, Moheon-Myeon, Cheoin-Gu, Yongin-Si, Gyeonggi-Do, Republic of Korea (e-mail: crystalslee97@gmail.com, changeric97@gmail.com). which, due to a lack of oxygen, leads to incapability to sustain plant growth and animal life. Salt reduces productivity and, in the most serious cases, leads to generalized plant death, limiting nutrient absorption and reducing the quality of available water. [5]

In soil ecosystem, soil microorganisms have important and diverse roles in that they degrade virtually all organic compounds, and 80 to 90 percent of the processes in soil are reactions mediated by microbes [6]. Among the diverse soil microorganisms, soil microorganisms such as Dehalobacter restrictus have been found to effectively decompose PCE (tetrachloroethylene) into ethylene through reductive dechlorination [7]. Harmful pesticides can also be decomposed almost $99 \%$ by certain types of soil bacteria [8].

Concerned about these interrelated issues, we chose to delve into topic of dechlorination of food waste by utilizing soil microorganisms. Approaching the issue with an effective and cost efficient method, we decided to turn foodwaste into a form of 'char'. Microorganisms that decompose organochlorine materials are crucial for our experiment, since we expect them to decompose chloride ions from the $\mathrm{NaCl}$ that exist in food wastes.

\section{EXPERIMENTAL METHODS}

\section{A. Purpose of Experiment}

The experiments were performed under three purposes. First, to investigate the influence of soil bacteria and variations in its concentration on dechlorination. Second, to observe the growth of lettuce that grew with the injection of both $\mathrm{NaCl}$ and soil bacteria. Third, to identify how soil bacteria should be treated when creating foodwaste char for the best outcome of lettuce growth.

\section{B. Preliminary Experiments}

\section{1) Production of the bacterial culture ground and cultivation of soil bacteria}

Nutrient Agar $(23 \mathrm{~g} / \mathrm{L})$ and Nutrient Broth $(8 \mathrm{~g} / \mathrm{L})$ were put in an autoclave under $121^{\circ} \mathrm{C}$ and run for 15 minutes. They were then mixed in a Petri dish and $50 \mathrm{~mL}$ tube, and cooled. To cultivate soil bacteria, $1 \mathrm{~g}$ of soil was placed in $10 \mathrm{~mL}$ of distilled water and heated under $50^{\circ} \mathrm{C}$ for 30 minutes. Afterwards, $100 \mathrm{uL}$ of the solution was put in liquid culture ground and cultivated it for one day under $27^{\circ} \mathrm{C}$.

\section{2) Measuring voltage and $p H$}

We checked the electric conductance of $\mathrm{NaCl}$ resulting from oxidation-reduction reaction of sodium and chloride ions. By connecting a piece of copper to the positive charge and zinc to the negative, we examined and compared the 
resulting voltages. The $\mathrm{pH}$ of the samples were also measured.

3) Measuring chlorophyll

In order to measure the amount of chlorophyll in the leaves, lettuce leaves were put in $10 \mathrm{~mL}$ of $99 \%$ alcohol for one day. After chlorophyll was removed, we put the samples in a spectrophotometer and measured the absorbance with wavelengths of $630 \mathrm{~nm}$ (chlorophyll a) and $645 \mathrm{~nm}$ (chlorophyll b).

\section{4) Pre-treatment of food waste and the production of char}

Because high salinity can affect plant growth, $100 \mathrm{~g}$ of food waste and $200 \mathrm{~mL}$ of distilled water was mixed, thereby decreasing the salinity to $0.2 \%$ and neutralizing the $\mathrm{pH}$ from 5.32 to 5.7. After filtering the solution with a sieve and removing the moisture, we mixed it again with $200 \mathrm{~mL}$, resulting to $\mathrm{pH} 5.73$ and $0 \%$ salinity. We diluted the solution again, and the $\mathrm{pH}$ measurement was 5.6. Then, we eliminated the moisture in food waste with a Drying Oven under $200^{\circ} \mathrm{C}$. The food waste was burned with a torch for 5 minutes and transformed into char.

\section{Experiment Execution}

1) Changes in the concentrations of soil bacteria and chloride ions depending on the concentration of $\mathrm{NaCl}$

We investigated whether any change is made on soil bacteria due to the amount of $\mathrm{NaCl}$ within food waste, and whether soil bacteria can effectively separate the chloride ions of $\mathrm{NaCl}$. Mixing $\mathrm{NaCl}$ and distilled water, we created solutions of five different concentrations- $0 \%, 0.1 \%, 0.25 \%$, $0.5 \%$ and $1 \%$. After putting $200 \mathrm{uL}$ of soil bacteria culture solution in each tube, we cultivated them in a bacterial culture medium for a week under $27^{\circ} \mathrm{C}$. Next, we spread each solution on the NA culture ground, and using a spectrophotometer, measured the absorbance of each solution to check whether there was any change on the bacteria.

In order to check whether the chlorine ions of $\mathrm{NaCl}$ were decomposed effectively, we put $1 \mathrm{~mL}$ of $0.1 \mathrm{M} \mathrm{AgNO}_{3}$ solution into $0.5 \mathrm{~mL}$ supernatant liquid of the solution of soil bacteria and $\mathrm{NaCl}$ that had been centrifuged. By this process, we were able to observe the precipitation reaction of $\mathrm{AgNO}_{3}$ and $\mathrm{NaCl}$ and measured their absorbance, as it can be observed in Fig. 1.

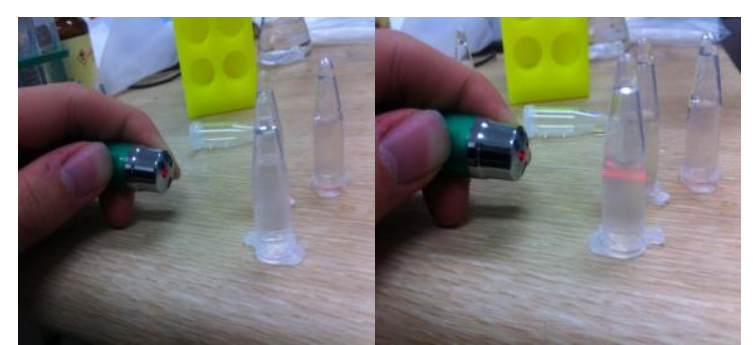

Fig. 1. Laser going through the solution of $0.1 \mathrm{M} \mathrm{AgNO}_{3}$ and $\mathrm{NaCl}$ microtubes -left) before mixing $\mathrm{AgNO}_{3}$ right) after mixing $\mathrm{AgNO}_{3}$.

Finally, we injected soil bacteria into each of the 4 solutions with different concentrations of $\mathrm{NaCl}-0.1 \%, 0.25 \%$, $0.5 \%$ and $1 \%$ and measured the electric conductance three times. We also measured the voltage of the solution that did not contain soil bacteria three times, and compared the average values.

\section{2) The effects of soil bacteria and $\mathrm{NaCl}$ on lettuce growth}

The purpose for this step was to examine the changes in lettuce growth with a fixed salinity of $2 \%$, the minimum concentration of salt when processing food waste. We put wet gauzes on 4 small plastic plates, placed 25 lettuce seeds on each plate and evenly dropped $1 \mathrm{~mL}$ of $2 \% \mathrm{NaCl}$ solution over each gauze. Then, we added different amounts of soil bacterial culture solution $-100 \mathrm{uL}, 200 \mathrm{uL}, 300 \mathrm{uL}, 400 \mathrm{uL}$ for each plate. Two weeks later, we compared the growth lengths (roots and stems) of lettuce and absorbance of chlorophyll using wavelengths of $645 \mathrm{~nm}$ and $663 \mathrm{~nm}$.

In order to further investigate the decomposition of chlorine ion under such conditions, we put different amounts $(100 \mathrm{uL} \sim 400 \mathrm{uL})$ of soil bacteria into $1 \mathrm{~mL}$ of $2 \% \mathrm{NaCl}$ solution in 4 tubes, and added $\mathrm{AgNO}_{3}$ to each. These were cultivated under $27^{\circ} \mathrm{C}$, and the absorbance of the consequently formed $\mathrm{AgCl}$ were measured.

\section{3) The effects of food waste char with variations in treatment methods of soil bacteria}

a) The growth changes of lettuce when treated with food waste char and activated carbon

Before investigating the effects of food waste char on lettuce growth, we mixed $0.77 \mathrm{~g}$ of food waste char which was obtained from our preliminary experiment with $10 \mathrm{~g}$ of soil, and planted 25 lettuce seeds in it. This process was applied to activated carbon, which was also mixed with $10 \mathrm{~g}$ of soil and 25 lettuce seeds planted within. For what we would use as the control group, we planted 25 lettuce seeds in $10 \mathrm{~g}$ of soil only. The subsequent changes in $\mathrm{pH}$ were observed.

b) The growth changes of lettuce with the usage of char made with simultaneous fermentation of soil bacteria and food waste

In this step, we attempted to verify whether the chlorine ions of $\mathrm{NaCl}$ become separated and eliminated when soil bacteria and food waste are treated together. To do so, we put $10 \mathrm{~g}$ of food waste and $400 \mathrm{uL}$ of soil bacteria in $25 \mathrm{~mL}$ of $\mathrm{NB}$ culture ground, transformed this into char and implemented the char on $10 \mathrm{~g}$ of soil. Along with this, we created char after fermenting only food waste without soil bacteria. We compared the lettuce growths under these two conditions.

c) The growth changes of lettuce with of the addition of soil bacteria after the production of food waste char

Lettuce did not grow well when the char made by the simultaneous treatment of food waste and soil bacteria was used. To test a different method, we decided to identify whether the outcome would be better when soil bacteria is injected after producing char with food waste. We created $1 \mathrm{~g}$ of char by burning $40 \mathrm{~g}$ of food waste that had been insulated for 3 months. The food waste was rinsed in water three times before being burnt. After creating a solution of $1 \mathrm{~g}$ of char and $10 \mathrm{~mL}$ of distilled water, we equally distributed this solution into 4 tubes and added 0, 200,400,600uL of soil bacteria in each. Each resulting solution with different amounts of soil bacteria was spread over a gauze, and planted 25 lettuce seeds. After one week, we compared the number of seeds that had sprouted and absorbance of chlorophyll.

We added a final step because the produced char had a $\mathrm{pH}$ of approximately 10 . To lessen such high $\mathrm{pH}$, we injected soil bacteria after diluting the char $\times 1000$ to $\times 20000$. By 
measuring the absorbance of chlorophyll, we were able to determine the char concentration that is most helpful to lettuce growth.

\section{RESULTS}

\section{A. Changes on Soil Bacteria, Chloride Ions and Voltage Depending on the Concentration of $\mathrm{NaCl}$}

In order to investigate soil bacteria following the variations in the concentration of $\mathrm{NaCl}$, we observed the changes on soil bacteria within the liquid culture ground that had been cultivated for a week after treating soil bacteria in $0.1 \%$, $0.25 \%, 0.5 \%$ and $1 \% \mathrm{NaCl}$ solution. The results are shown in Fig. 2.

The absorbance of soil bacteria had decreased by approximately $0.1 \sim 0.2 \mathrm{~A}$ compared to that of $0.1 \% \mathrm{NaCl}$. Even when soil bacteria was injected in $\mathrm{NaCl}$ solution and cultivated, they grew regardless of the $\mathrm{NaCl}$ concentration, as it can be observed in Fig. 3. Therefore, since it does not decrease greatly depending on the concentration of $\mathrm{NaCl}$ and is cultivated in bacterial culture growth, soil bacteria can endure sufficiently high salinity.

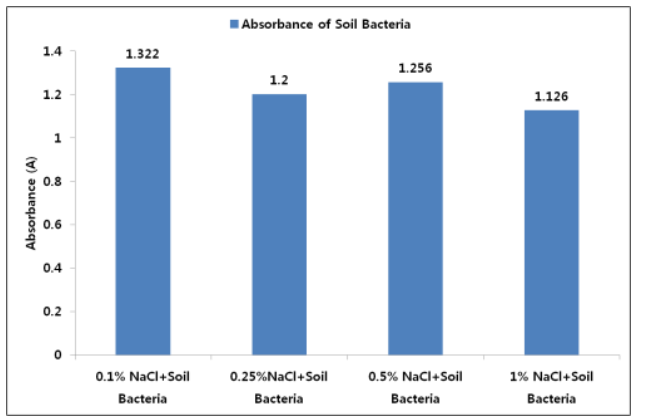

Fig. 2. Soil bacteria and the concentration of $\mathrm{NaCl}$.

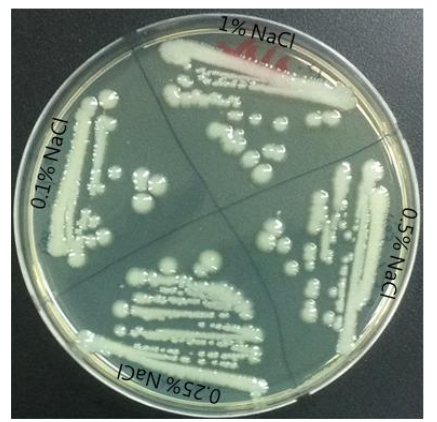

Fig. 3. Culture ground after treating soil bacteria in $\mathrm{NaCl}$ solution.

TABLE I: CHANGES IN VOLTAGE AS NACL CONCENTRATION INCREASES

\begin{tabular}{|l|l|l|l|l|}
\hline & $0.1 \% \mathrm{NaCl}$ & $0.25 \% \mathrm{NaCl}$ & $0.5 \% \mathrm{NaCl}$ & $1 \% \mathrm{NaCl}$ \\
\hline Soil Bacteria & 0.026 & 0.04 & 0.04 & 0.06 \\
\hline Control & 0.023 & 0.033 & 0.046 & 0.05 \\
\hline
\end{tabular}

The results of the absorbance of $\mathrm{AgCl}$ for examining the dechlorination reaction of $\mathrm{NaCl}$ are as the following, as shown in Fig. 4: The absorbance of $\mathrm{NaCl}$ of concentrations $0.1 \% \sim 1 \%$ were $0.802 \sim 0.813 \mathrm{~A}$, and after the injection of $100 \mathrm{uL}$ of soil bacteria, the absorbance of $\mathrm{AgCl}$ increased to $0.864 \sim 0.904 \mathrm{~A}$.

Even in this case, since changes in concentration did not significantly contribute to the changes in absorbance, it seemed to be that the soil bacteria within the $100 \mathrm{uL}$ evenly caused dechlorination reaction.

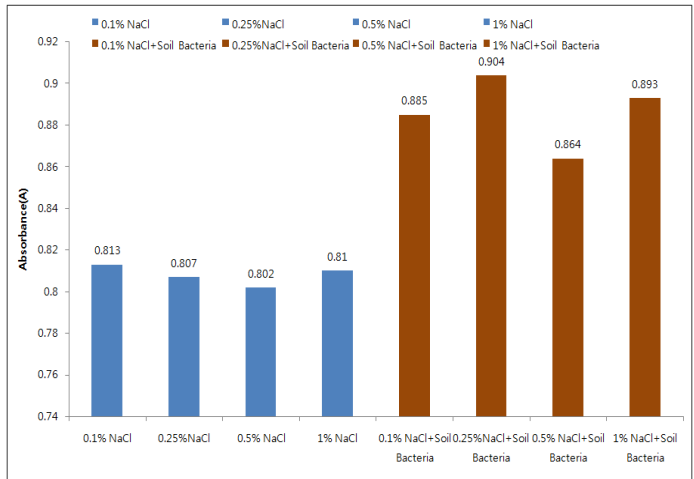

Fig. 4. Changes of $\mathrm{AgCl}$ 's absorbance (blue - $\mathrm{NaCl}$ without soil bacteria, red - $\mathrm{NaCl}$ with soil bacteria).

In order to verify the decomposition of chloride ions depending on soil bacteria and the $\mathrm{NaCl}$ concentration, pieces of zinc and copper were connected to each solution and the voltages were observed. As a result, the voltages of solutions with soil bacteria overall were measured to be higher. The measurement of voltage is shown in Table I.

It could thus be projected that soil bacteria cause dechlorination reaction at a fixed degree of salinity.

\section{B. Changes in Chloride Ions and Soil Bacteria in $2 \%$ $\mathrm{NaCl}$ Solution Depending on the Amount of Soil Bacteria}

With the concentration of $\mathrm{NaCl}$ solution fixed as $2 \%$, whether there were changes in soil bacteria when different amounts of soil bacteria were put in was observed. The results are shown in Fig. 5.

Contrary to the expectation that absorbance would increase as more soil bacteria is put in, except the resulting $1.301 \mathrm{~A}$ from $100 \mathrm{uL}$ of soil bacteria, the absorbance of soil bacteria in the others were almost constant $(1.042 \sim 1.114 \mathrm{~A})$. Thus, it could be seen that in $2 \% \mathrm{NaCl}$ solution, soil bacteria do not continue propagating but maintain a certain number.

The absorbance of $\mathrm{AgCl}$ was observed so that the changes in the concentration of chloride ions with the increase of the concentration of soil bacteria could be examined. Consequently, it was measured that the absorbance of $2 \%$ $\mathrm{NaCl}$ solution was 0.764 , but that of the solutions with soil bacteria was higher. However, there was no increase of the concentration of chloride ions led by the increase of the concentration of soil bacteria. The reason for this was projected to be that because soil bacteria maintain a constant amount in $2 \% \mathrm{NaCl}$ solution and cannot be cultivated more, there is no change in the concentration of chlorine ions also.

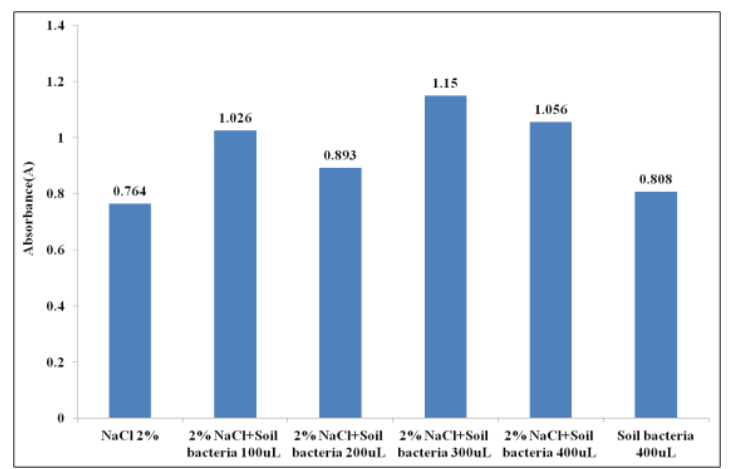

Fig. 5. Absorbance of $\mathrm{AgCl}$ when the amount of soil bacteria differed in $2 \%$ $\mathrm{NaCl}$ solution. 


\section{The Effects of Soil Bacteria and $\mathrm{NaCl}$ on Lettuce Growth}

The growth of lettuce when the seeds were given $2 \% \mathrm{NaCl}$ solution and soil bacteria was checked. All the seeds that were planted in gauze with only $2 \% \mathrm{NaCl}$ failed to sprout. However, all the seeds that were provided with both $2 \% \mathrm{NaCl}$ and $100 \mathrm{uL} \sim 400 \mathrm{uL}$ of soil bacteria sprouted with well-grown roots and stems. The results are shown in Fig. 6.

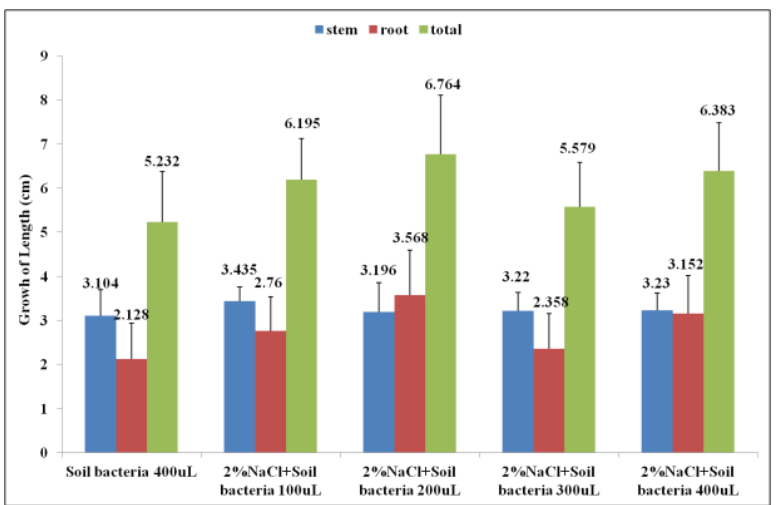

Fig. 6. The growth of lettuce when $2 \% \mathrm{NaCl}$ solution and soil bacteria were treated.

Upon observing the absorbance of chlorophyll, it was found that the lettuce treated with both $2 \% \mathrm{NaCl}$ and soil bacteria generally had higher absorbance than lettuce that were treated with only soil bacteria, as it is demonstrated in Fig. 7. The lettuce treated with $200 \mathrm{uL} \sim 400 \mathrm{uL}$ of soil bacteria especially had high and consistent absorbance, ranging from 0.253 A to $0.262 \mathrm{~A}$.

Small concentration of chloride ions can facilitate hydrolysis during photosynthesis, so it is projected that chloride ions decomposed by soil bacteria helped the growth of lettuce. However, too much chloride ions hinder growth, so $2 \% \mathrm{NaCl}$ was not a suitable condition for the lettuce to grow.

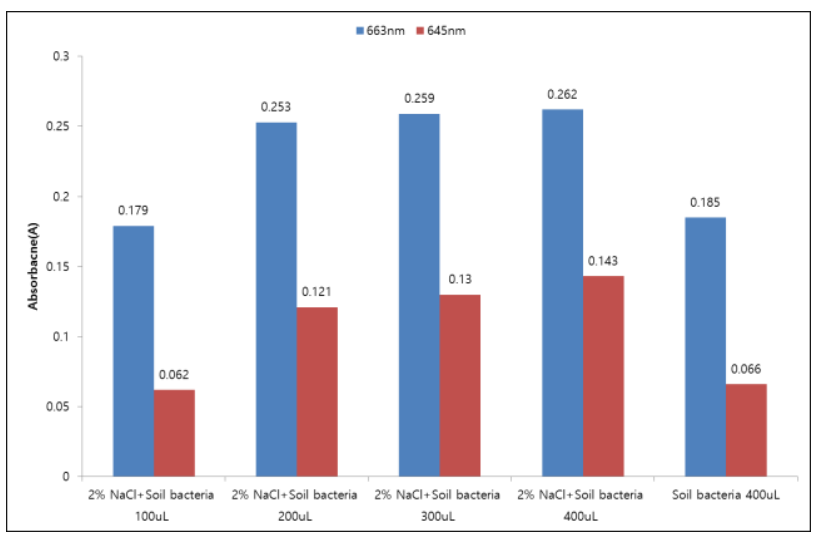

Fig. 7. Changes in the absorbance of chlorophyll when soil bacteria was put in $2 \% \mathrm{NaCl}$ solution.

\section{The Effects of Food Waste Char with Variations in Treatment Methods of Soil Bacteria}

1) Changes in lettuce growth when food waste char and activated carbon were treated

For this trial, we did not mix any soil bacteria with food waste char, and instead implemented the char directly onto the soil. The result showed that the absorbance of lettuce that were grown in soil that included food waste char or activated carbon decreased compared to the control group.
2) Changes in the growth of lettuce when food waste and soil bacteria were treated together and made into char

We thought that if food waste and soil bacteria are cultivated on liquid culture ground and fermented together, soil bacteria would cause dechlorination and thus prevent $\mathrm{NaCl}$ from hindering the growth of the lettuce.

As Fig. 8 shows, the control group had the highest absorbance of chlorophyll in the leaves. On the other hand, lettuce that was treated with foodwaste char that was made from food waste mixed with soil bacteria had the lowest absorbance.

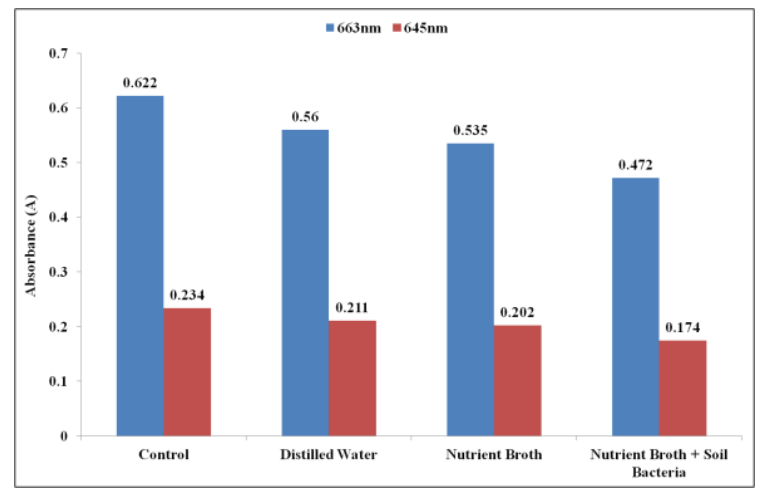

Fig. 8. Changes in the light absorbance of chlorophyll when lettuce was treated with soil bacteria and food waste that had been fermented together.

We extracted $1 \mathrm{~g}$ of soil that was treated with food waste char and mixed it with $1 \mathrm{~mL}$ of distilled water. We then filtered the soil and measured the $\mathrm{pH}$ and absorbance of $\mathrm{AgCl}$. The data is shown in Fig. 9.

Compared to the control group, the soil that was treated with food waste char displayed alkalescence, not significantly influencing the growth of plants.

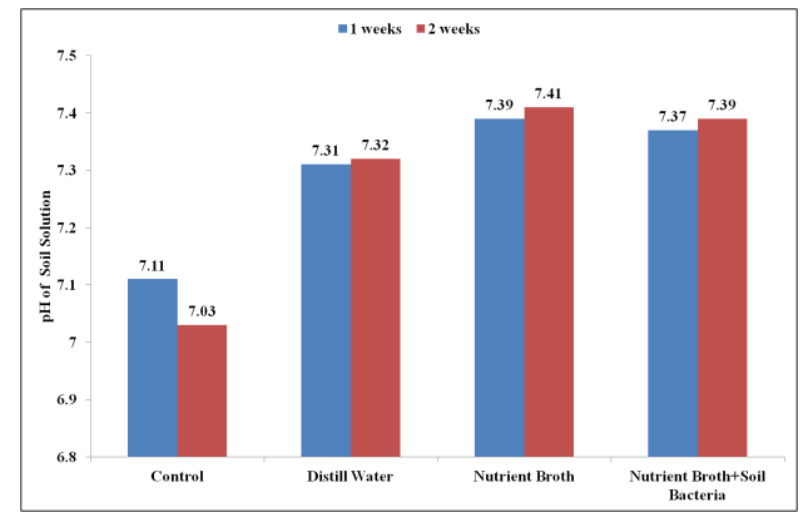

Fig. 9. Changes in the $\mathrm{pH}$ of soil when treated with food waste char that was fermented with soil bacteria.

The absorbance of $\mathrm{AgCl}$ was different from that of chlorophyll, having the highest value of chloride ion concentration when soil bacteria were put in.

Based on this result, we thought that when food waste and soil bacteria are treated together and dechlorination from $\mathrm{NaCl}$ occurs too much, the concentration of chloride ions increases drastically, thus limiting plant growth instead of helping it.

\section{E. Changes Lettuce Growth When They Were Treated with Soil Bacteria after Food Waste Char was Created}

There were two categories; one had food waste char with 0 $\sim 600 \mathrm{uL}$ of soil bacteria, and the other had $\times 1000$ diluted food 
waste char solution with the same amount of soil bacteria. The lettuce leaves were observed with naked eye and infrared camera (photo shown in Fig. 10 and Fig. 11, respectively). Well-developed leaves absorb more water, resulting in lower temperature, so infrared cameras capture such points in green or blue. The camera showed that the lettuce that had grown with diluted food waste char had more green and blue leaves compared to those that had grown with non-diluted char.

\begin{tabular}{|c|l|l|l|l|l|}
\hline $\begin{array}{c}\text { Soil } \\
\text { Bacteria }\end{array}$ & $600 \mathrm{uL}$ & 400uL & 200uL & OuL & Control \\
\hline $\begin{array}{l}\text { Food Waste } \\
\text { Char Solution }\end{array}$ & & & & &
\end{tabular}

Fig. 10. Lettuce growth when food waste char solution and diluted food waste char solution were treated.

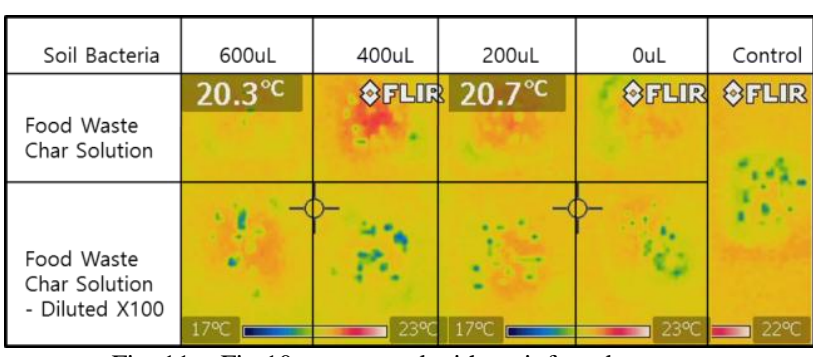

Fig. 11. <Fig 10. > captured with an infrared camera.

Thus, as Fig. 12 demonstrates, the lettuce treated with non-diluted food waste char solution had lower absorbance than that of the control group $(0.467 \mathrm{~A})$. For diluted food waste char solution, the lettuce treated with $600 \mathrm{uL}$ of soil bacteria had higher absorbance $(0.541 \mathrm{~A})$ than that of the control group, but the others showed lower values.

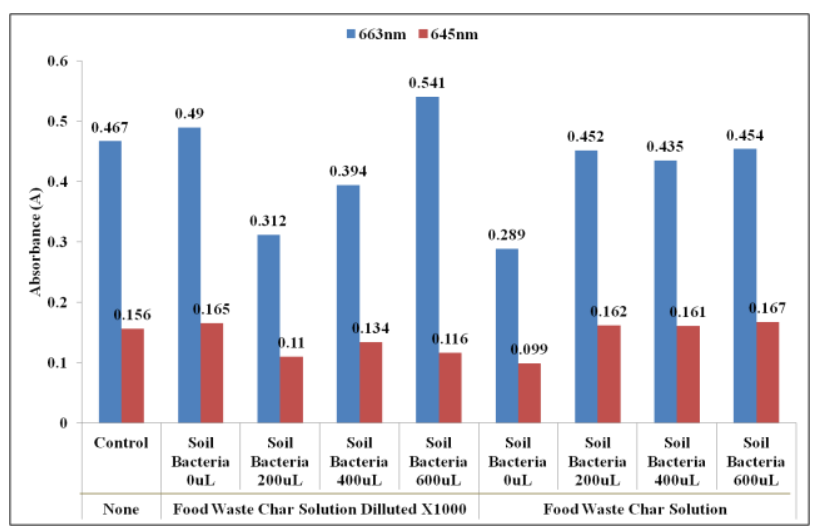

Fig. 12. Changes in lettuce leaves' chlorophyll when treated with food waste char solution (diluted $\times 1000)$.

On the grounds that more dilution would promote plant growth, $500 \sim 20000$ times diluted solutions were made and mixed with the solutions of $600 \mathrm{uL}$ of soil bacteria. The growth of lettuce was observed once more. Fig. 13 shows the lettuce leaves that were treated with $500 \sim 20000$ times diluted solutions.

The infrared camera showed that the lettuce treated with just the diluted solution had similar color of leaves to those of the control group (Fig. 14). The lettuce treated with the diluted solution and soil bacteria had deeper blue leaves.

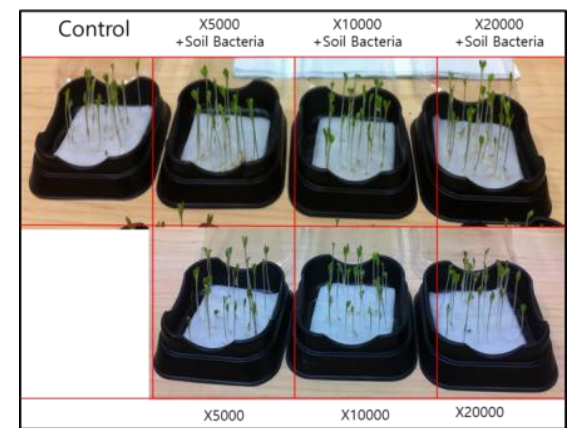

Fig. 13. Changes of lettuce growth when treated with 5000 20000times diluted solutions and soil bacteria.

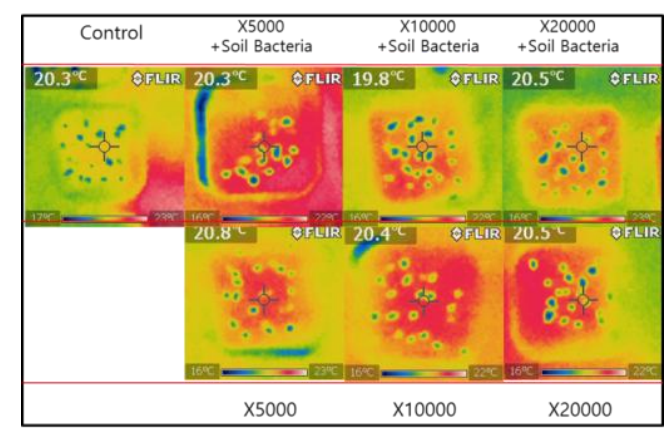

Fig. 14. <Fig 13. > captured with infrared camera.

When checking the amount chlorophyll in the leaves, it was observed that lettuce treated with diluted solution had higher absorbance than those of the control group, and leaves treated with diluted solution and soil bacteria had even higher absorbance. This data in Fig. 15 almost perfectly matches with the data attained with the infrared camera.

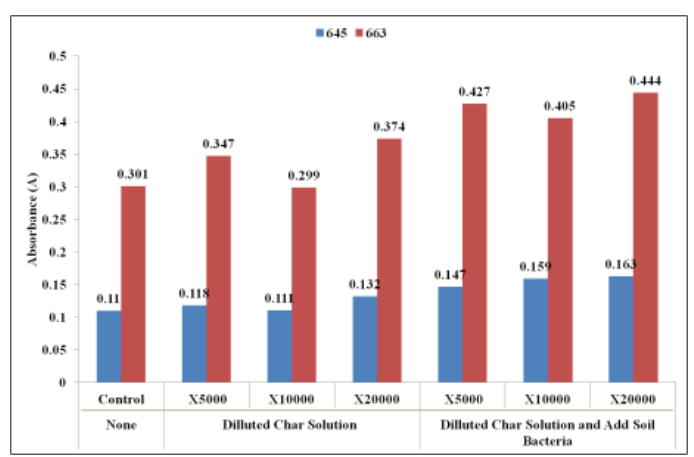

Fig. 15. Changes in the amount of chlorophyll of lettuce when treated with 5000 20000 times diluted solution.

\section{CONCLUSION}

\section{A. The Effect of Soil Bacteria on Dechlorination Reaction}

When soil bacteria was put in solutions of $0.1 \sim 1 \% \mathrm{NaCl}$, the amount of soil bacteria remained constant. The absorbance of $\mathrm{AgCl}$ was generally higher than that of the control group, but also fairly constant. When there were variations on the amount of soil bacteria in $2 \% \mathrm{NaCl}$ solution, it was found that the amount of soil bacteria neither increased nor decreased, maintaining a consistent amount. These results illustrate that the growth of soil bacteria is restricted in a solution with a certain degree of concentration, but among those there are some soil bacteria that have tolerance to salt, and there are others that cause dechlorination reaction.

\section{B. The Effect of Chlorine on Plant Growth}


When $2 \% \mathrm{NaCl}$ was treated on the lettuce, the seeds did not sprout, but they did when soil bacteria were treated along with $\mathrm{NaCl}$. Some lettuce that were given both $\mathrm{NaCl}$ and soil bacteria had more chlorophyll than those that were given soil bacteria. Presumably, the reason for this is that chloride ions facilitate hydrolysis during photosynthesis, so the small amount of decomposed chloride ions from $\mathrm{NaCl}$ would help plant growth.

\section{The Optimal Treatment of Soil Bacteria on Food Waste Char}

The advantages of transformation into char are that it can keep the soil moist, provide nutrients to plants, and help the soil sustain more soil bacteria. Using only food waste char did not enhance lettuce growth, and when soil bacteria was fermented with food waste and burned together, the resulting char rather hindered the plants from growing. Possibly, there was excessive dechlorination reaction for this case, and too much chloride ions would have hindered the growth of lettuce.

When soil bacteria were added after food waste char was produced, the char was found to be too alkaline. Because of this, the solution that included the char had to be diluted in order to support plant growth. The lettuce that were given diluted solutions and soil bacteria performed best, especially those that were given $\times 20000$ diluted solution and $600 \mathrm{uL}$ of soil bacteria, having more chlorophyll (1.043 A) than the control group.

\section{FURTHER EXPERIMENTS}

Up to now, there have generally been many scientific researches related to food waste fertilizers. Based on this fact, we did a research on what kind of advantages there would be on crops such as lettuce if soil bacteria are absorbed in char and applied to soil. As a result, because soil bacteria included microorganisms that cause salt tolerance and dechlorination reaction, it could prevent growth hindrance of plants led by $\mathrm{NaCl}$ and be effective in plant growth overall.

Such produced char can, depending on the degree of dilution, not only be used in restoring acidified soil, but also be used as a fertilizer that can promote plant growth. Thus, on the basis of this research, in the future, we want to head further and verify whether food waste char can actually be applied to acidified soil and whether it can be connected to the well-known absorption effect of heavy metals of char.

\section{REFERENCES}

[1] A. Gudo and M. Singarvelu, "Global biomethanation potential from food waste - A review," Agricultural Engineering International: CIGR Journal, vol. 16, no. 4, pp. 178-192, Dec. 2014.

[2] G. Park and H. Baek, "Producing char using food waste by compression molding," ROK Patent 10-2010-0119763, November 29, 2010.

[3] Y. Baek, J. Lee, S. Park, and S. Bae, "The characteristics of the biochar with the synthetic food waste and wood waste for soil contaminated with heavy metals," Journal of Soil and Groundwater Environment, vol. 19, no. 1, pp. 1-7, 2014.

[4] N. A. Tejera, R. Campos, J. Sanjuan, and C. Lluch, "Effect of sodium chloride on growth, nutrient accumulation, and nitrogen fixation of common bean plants in symbiosis with isogenic strains," Journal of Plant Nutrition, vol. 28, no. 11, pp. 1907-1921, Sept. 2004.

[5] A. Heidari, M. Toorchi, A. Bandehagh, and M. Shakiba, "Effects of different $\mathrm{NaCl}$ concentrations on germination and seedling growth of amaranthus hybridus and celosia argentea," Universal Journal of Environmental Research and Technology, vol. 1, no. 3, pp. 351-362, 2011.

[6] P. Nannipieri, J. Ascher, M. T. Ceccherini, L. Landi, G. Pietramellara, and G. Renella, "Microbial diversity and soil functions," European Journal of Soil Science, vol. 54, pp. 655-670, Dec. 2003.

[7] G. Ariel and E. A. Edwards, "Growth of dehalobacter and dehalococcoides Spp. during degradation of chlorinated ethanes," Applied and Environmental Microbiology, vol. 72, no.1, pp. 428-436, 2006.

[8] J. Shin, Y. Kwak, W. Kim, J. So, H. Shin, J. Park, T. Kim, J. Kim, and I. Rhee "Isolation of endosulfan degrading bacteria and their degradation characteristics," Korean Journal of Environmental Agriculture, vol. 27, no. 3, pp. 292-297, 2009.

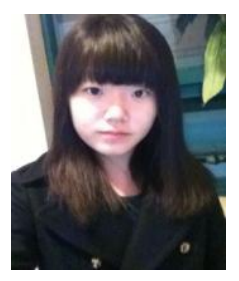

Soojung Lee was born in the Republic of Korea in 1997. She is currently enrolled in Hankuk Academy of Foreign Studies as an international major, and will be graduating in February 2016. Her interest covers a wide range of academic fields, including mathematics, chemistry and molecular biology. She plans to pursue her degrees in applied mathematics, materials science or molecular biology.

Her passion for scientific research has allowed her to have many laboratory work experiences, and she has been an intern at a nano-electrochemistry lab for the past two years. Currently, her greatest interest lies in how the method of Quorum Sensing can be employed for the detection of the antibiotic-resistant genes in MRSA.

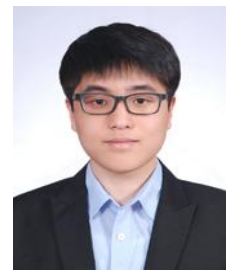

Seokyoon Chang was born in Gyeonggido, Republic of Korea in 1997. He is currently one part of the International Department at Hankuk Academy of Foreign Studies and will be graduating in February 2016. He has broad knowledge about science in general, and is mainly interested in studying biology and environmental science.

He has been involved in numerous academic experiences, leading student organizations regarding both English debating and ecology of the demilitarized zone dividing the two Koreas. He has also been an intern at DMZ Ecology Institute. He has led numerous researches and continues to delve into diverse topics in his field of interest. 